\title{
Independency Or Correlation? The GCC Stock Markets, Interest Rates, And Oil Prices: Against All Financial Rules
}

Viviane Y. Naïmy, (Email: vnaimy@ndu.edu.lb), Notre Dame University, Lebanon

\begin{abstract}
This paper examines the relationship(s) that exist among the four GCC stock markets: Kuwait, Saudi, UAE, and Oman. We observed and measured how and up to which extent oil prices, gold prices, and US interest rates affect these markets for the period 2005. We noticed a positive relationship between these markets and each factor and a perfect positive correlation between the Kuwaiti and Saudi markets.
\end{abstract}

\section{INTRODUCTION}

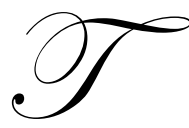

he Gulf States are experiencing unprecedented growth in their economies and particularly in their stock markets. The number of companies listed and traded has witnessed a serious increase in the four GCC countries, namely, Kuwait, Saudi, UAE, and Oman. Strong corporate results, coupled with increased business and consumer confidence in the region are sending the markets and indices to their all-time highest levels. The question is to see if this growth is based on real growth, sound market fundamentals, and realistic economic policies. Because of this continuous growth experienced in these four GCC countries, we decided to examine and measure the possible factors affecting these markets and the corresponding correlation between them.

We will present a short summary of each stock market. Then we explore the factors affecting the performance of these stock markets such as oil and gold prices, and interest rates. Finally, we examine the relationship(s) existing among these stock markets. For this purpose, we will use ${ }^{1}$ regression analysis, boxplots, distribution analysis, independence test, etc.

\section{BRIEF OVERVIEW OF THE FOUR STOCK MARKETS}

The Kuwait stock exchange index (KSE) was established in 1962 (October). It is the first largest and most important stock exchange in the Gulf region, and is one of the most important in the emerging markets countries.

The Muscat Securities Market (MSM) was established in 1988 (June), with the aim of regulating and controlling the Omani securities market and participating effectively with other organizations for setting up the infrastructure of the Sultanate's financial sector.

Major share offerings in the Saudi market were made in the 1970's to the public. The market remained informal, until the early 1980's when the Government embarked on a rapid development program ${ }^{2}$. In 1984, the Saudi Share Registration Company (SSRC) was established by the commercial banks ${ }^{3}$. Automated clearing and settlement was introduced in 1989. The Electronic Securities Information System (ESIS) was introduced in 1990. Tadawul, the

\footnotetext{
${ }^{1}$ The statistical package used is developed by Palisade Decision Tools, 2006

${ }^{2}$ In 1984, a Ministerial Committee consisting of Ministry of Finance and National Economy, Ministry of Commerce and SAMA was formed to regulate and develop the market.

${ }^{3}$ The company provides central registration facilities for joint stock companies and settles and clears all equity transactions.
} 
new securities trading, clearing and settlements was launched in October 2001. During the period 1996 - 2005, the number of transactions, volume and value traded increased dramatically. Market capitalization has increased by $1,490 \%$ and the all share index has increased by $1,122.04 \%$.

The Abu Dhabi Securities Market (ADSM) was established on 15 November 2000 by Local Law ${ }^{4}$, the provisions of which vest the Market with a legal entity of autonomous status, independent finance and management, and give ADSM the necessary supervisory and executive powers to exercise its functions. ADSM has the authority to establish centers and branches outside the Emirate of Abu Dhabi. To date it has done so in Fujeirah, Ras al Khaimah, Sharjah and Zayed City. In our study, the UAE market is represented by Abu Dhabi securities market index.

\section{Kuwait Stock Market}

The distribution of the Kuwaiti market index over the period 2005 indicates a relatively normal distribution ${ }^{5}$ justified by a value of 0.2881 for $p$ and indicating a good fit ${ }^{6}$.

\begin{tabular}{|c|c|}
\hline Chi-Square Test & Kuwaiti Index \\
\hline Mean & 131953.00 \\
\hline Std Dev & 339.72 \\
\hline Chi-Square Stat. & 6.1910 \\
\hline P-Value & 0.2881 \\
\hline
\end{tabular}

Figure 1: Distribution of the Kuwaiti Stock Market

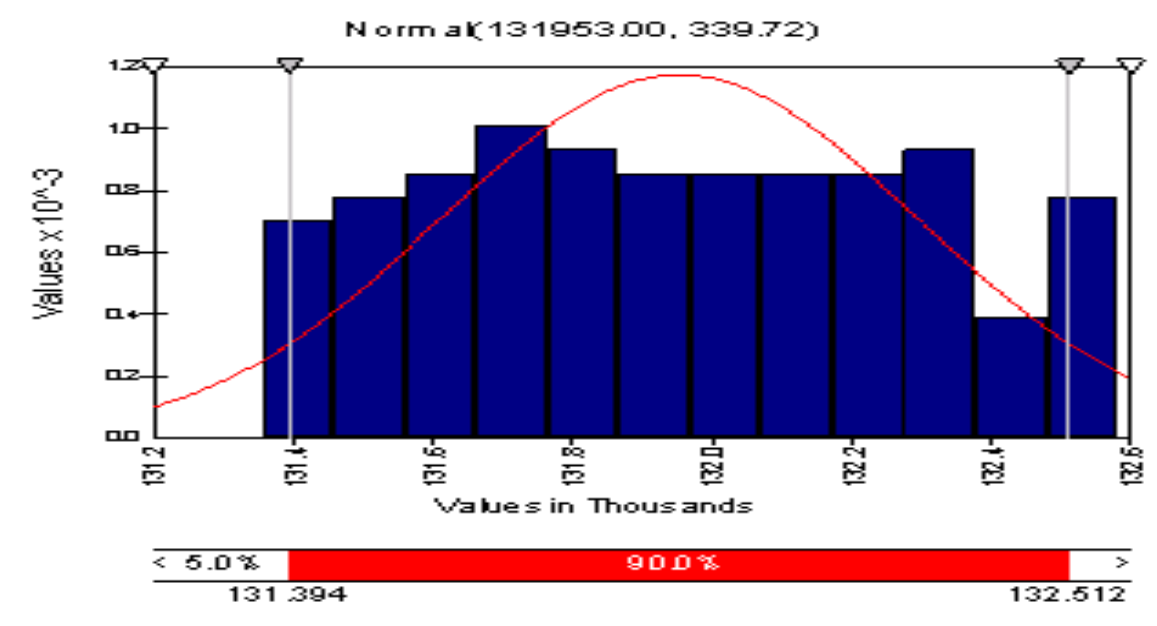

\section{Saudi Stock Market}

By studying the distribution of the Saudi market, we found approximately exactly ${ }^{7}$ the same results as for the Kuwaiti stock exchange market. The Chi-test for normality as illustrated bellow shows a normal distribution.

\footnotetext{
${ }^{4}$ No. (3) of 2000

${ }^{5}$ The resulting box plot shows a symmetry on each side of the median, where the mean is relatively close to the median. This is another confirmation for the normal distribution of this market.

${ }_{7}^{6}$ Using the best fit program, the closest given distribution was the normal one.

${ }^{7} \mathrm{p}$-value is 0.2881
} 
Figure 2: Chi-Square Distribution for Saudi Market

\section{ChI-square Tegt for saudl \$/Data set $\# 1$}

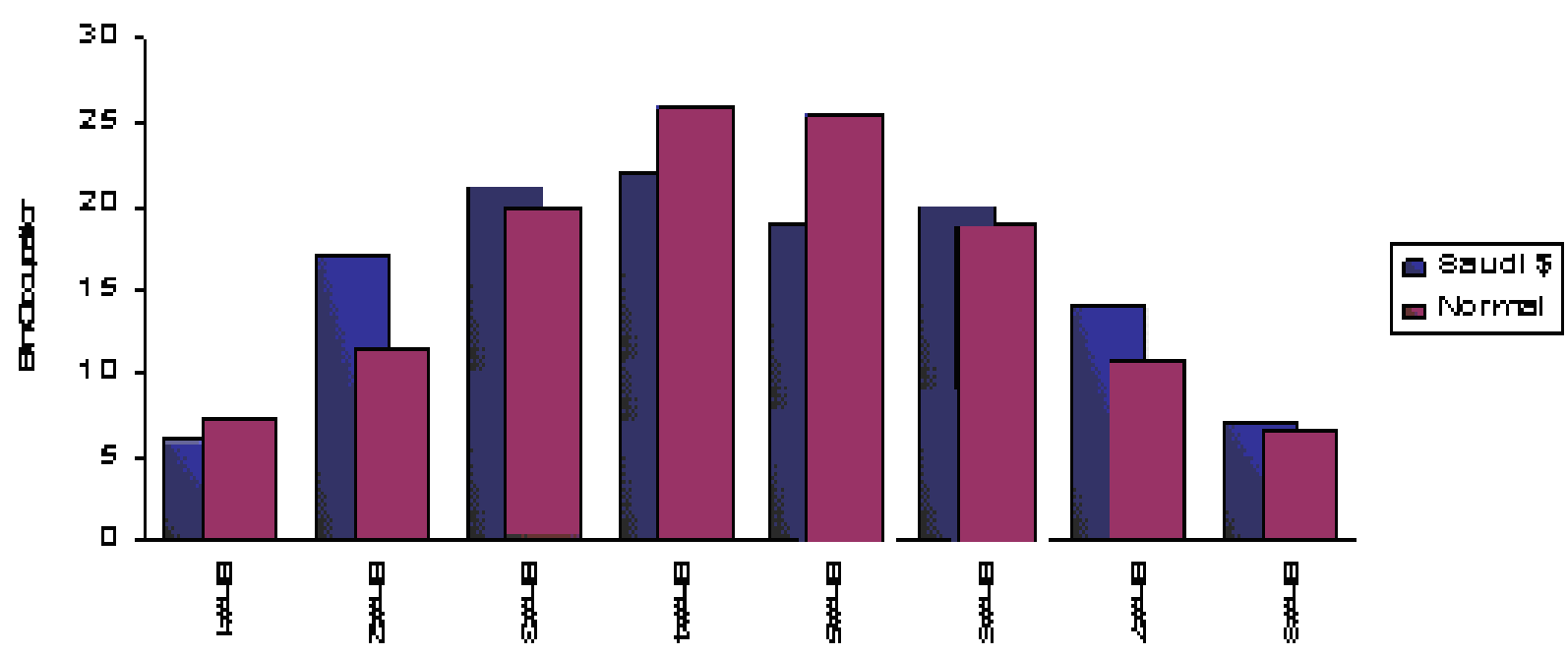

As the Kuwaiti market, the Saudi market index was facing a continuous and obvious increase over the last year.

Figure 3: Time Series - Saudi Market

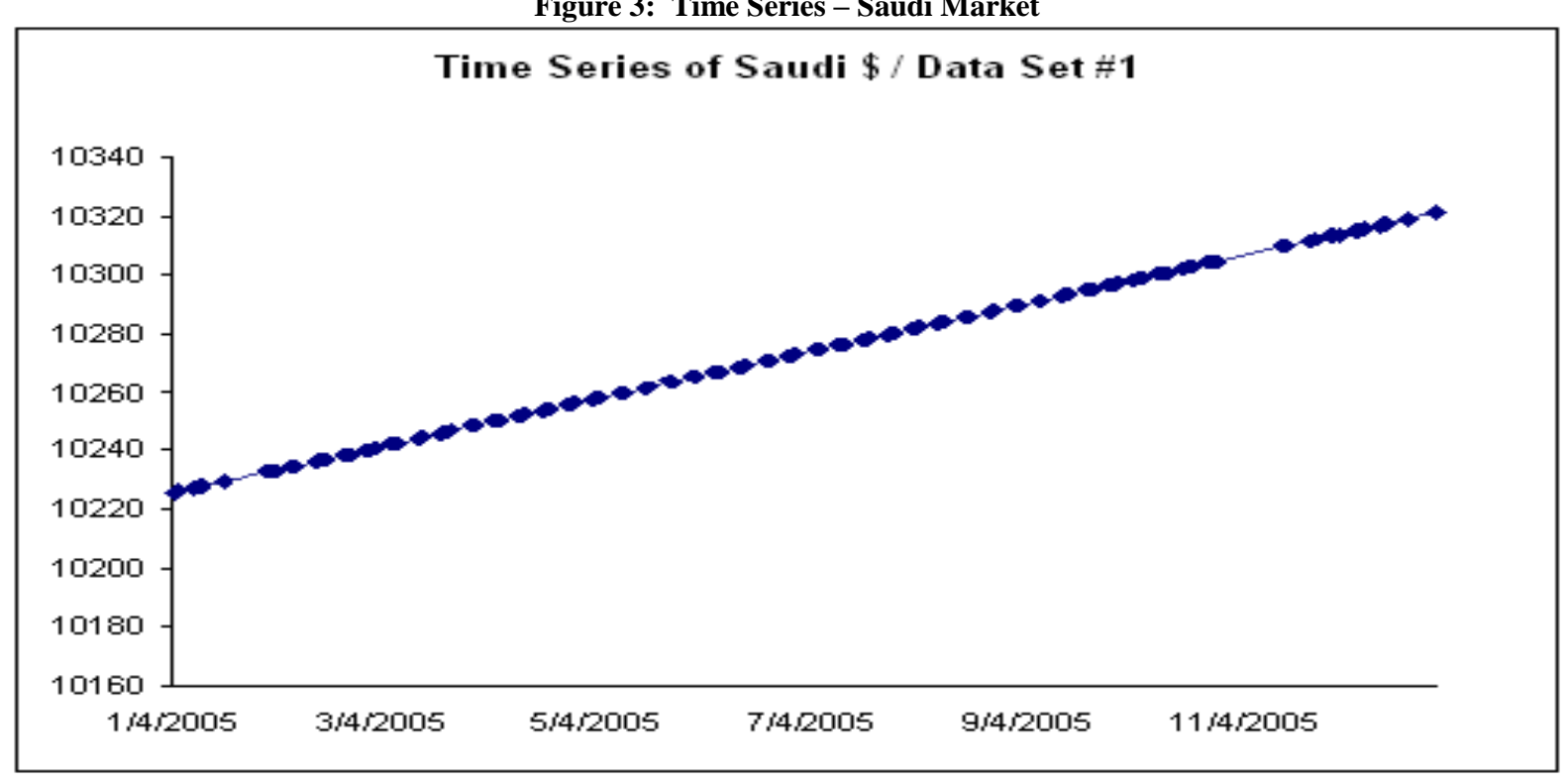

\section{Oman Stock Market}

Unlike the above two analyzed markets, the distribution of the Omani stock market over the same period is skewed to the left. This is indicated in the histogram in Figure 4 which shows that $45 \%{ }^{8}$ of the index value lies between 12548.80 and 13968.94 .

${ }^{8} 57$ observations 
Figure 4: Histogram for Oman Stock Market

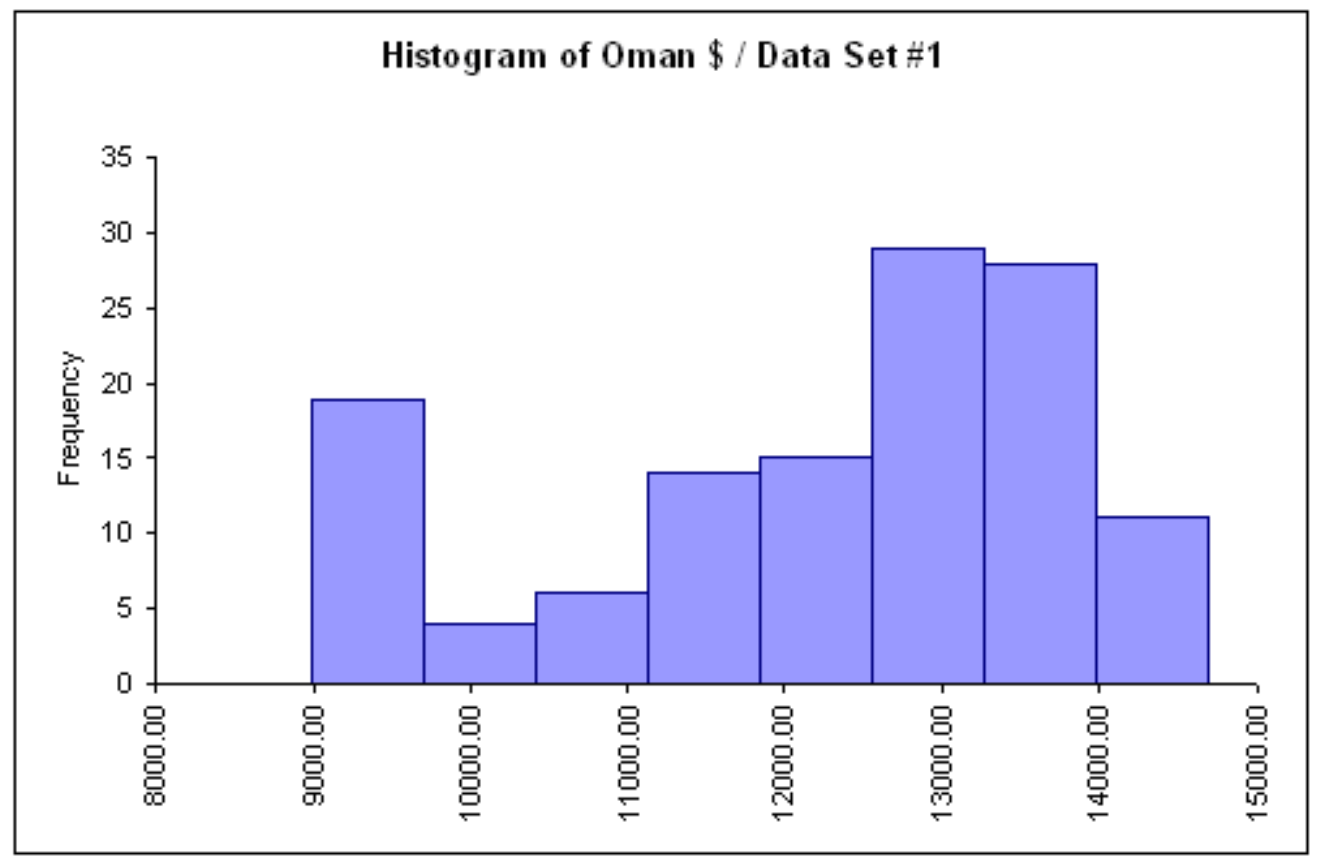

\section{Abu Dhabi Stock Market}

The distribution of the Abu Dhabi stock market is skewed to the left, where $57 \%$ of the prices lay between 1383.5 and 1587.58. The boxplot in Figure 5 gives a clear illustration of this distribution. The lower whiskers extend farther to the left than to the right of the boxes and the median is closer to the right side. There are few mild outliers to the left side of the box with no extreme outliers, meaning that this market is more volatile than the first two described ones.

Oman and Abu Dhabi markets were fluctuating during this period unlike the Saudi and Kuwaiti markets that witnessed a continuous increasing trend.

\section{JUSTIFICATION OF THE SELECTED FACTORS AND DATA DESCRIPTION}

The oil price plays an important role in shaping the movement of these stock markets. For these countries, oil exports largely determine their foreign earnings and their governments' budget revenues and expenditures. Thus, they represent the primary determinant of aggregate demand. On the other hand, the aggregate demand effect influences corporate output and domestic price levels, which eventually determine corporate earnings and stock market prices. This demand effect can also indirectly affect stock prices through its influence on inflation, which in turn is positively correlated to interest rates. The GCC interest rates are sensitive to changes in the US rates because their national currencies are fixed to the US dollar ${ }^{9}$.

Daily data for the GCC stock indices and the oil prices cover the period 4/1/2005 through 28/12/2005. The length of this period is limited by the availability of GCC data, which was collected piece by piece directly from individual exchanges. The US one-month interest rates were collected from the official site of the federal reserves statistical releases. They are collected daily and for exactly the same period. The oil prices used were the crude oil

\footnotetext{
${ }^{9}$ Whether one-on-one or through a basket of currencies dominated by the dollar.
} 
spot price (WTIS) which is the price of the West Texas Intermediate ${ }^{10}$ (WTI-Cushing). It is traded in the domestic spot market at the Cushing, Oklahoma center. The prices of crude oil are expressed in US dollars per barrel. The 2005 daily gold prices were collected from London Afternoon Gold Price Fixings and are expressed in US dollar.

Figure 5: Abu Dhabi Boxplot

Box Plot of Abudhabi $\$ /$ Data Set $\# 1$

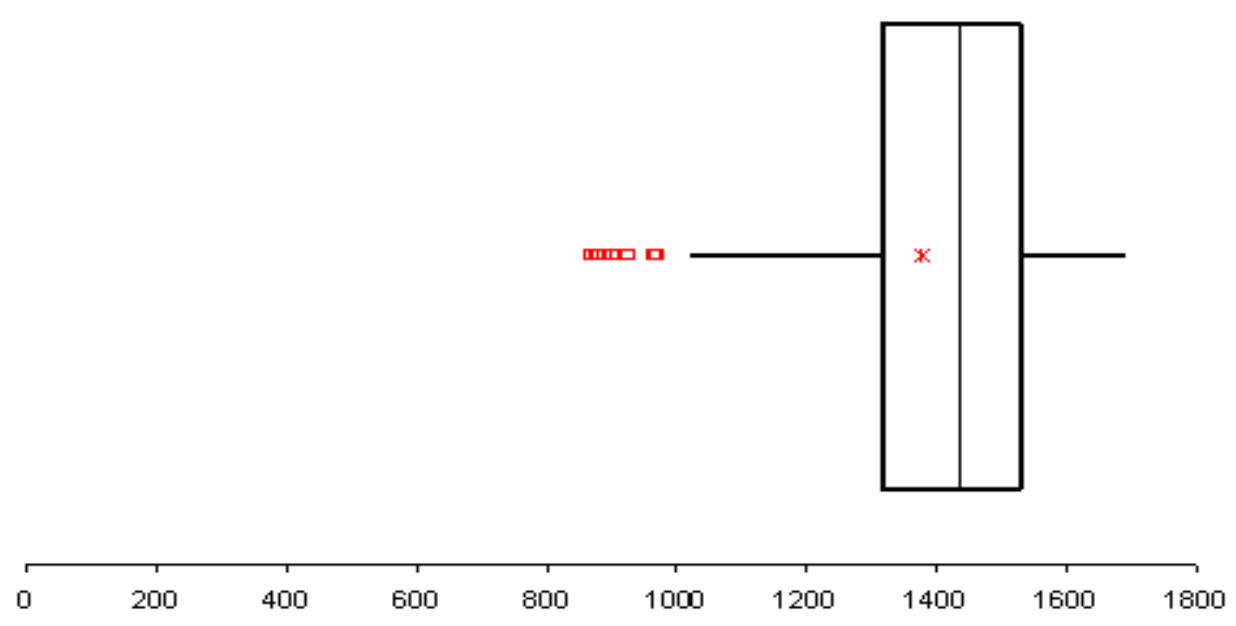

Stock Prices and Interest Rates: Against All Rules

The most amazing result among the variables that we are considering in this empirical research is the perfect positive correlation between the Kuwaiti and Saudi markets.

Figure 6: Scatterplot of Kuwait Vs. Saudi

\section{Scatterplot of Kuwait vs Saudi of Data Set \#1}

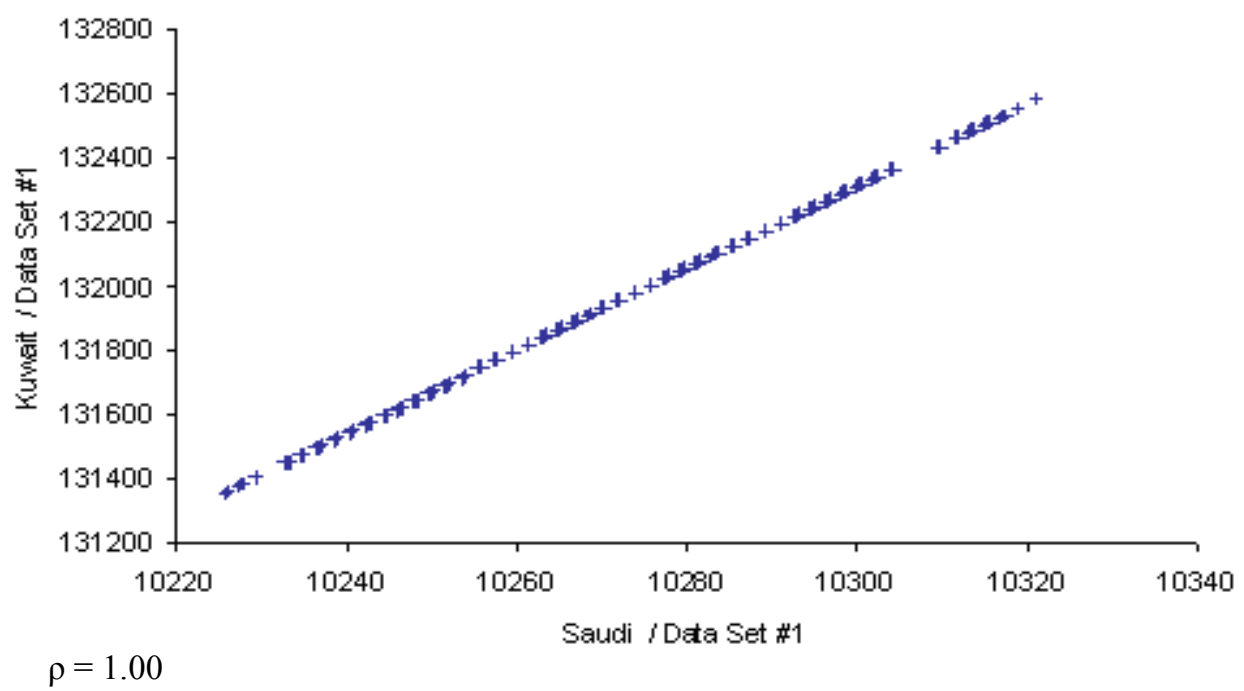

${ }^{10}$ It is a crude stream produced in Texas and southern Oklahoma. 
Consequently, exogenous variables are studied with only one of the two markets.

The first financial broken rule in these countries is illustrated in the positive relationship between stock prices and interest rates. Looking into the below correlation table (Table 1), we detect the important quite perfect correlation (0.990) between both, the Kuwaiti and Saudi markets, and interest rates. This observation constitutes a very significant tool for investors: any factor that might positively affect interest rates, such as oil prices, inflation, etc., is accompanied with an increasing tendency of stock prices in Kuwaiti and Saudi markets with the same sensitivity percentage toward the variability of that factor.

The second important conclusion to read from Table 1 is that investing in these markets when interest rates are increasing constitutes one of the appropriate hedging tools against increasing interest rates consequences. However, elasticities, all other things being equal, range between 0.99 (the highest) and 0.56 (the lowest), which still represent an efficient acceptable coefficient of gap hedging.

Table1: Correlation Between Interest Rates and Prices

\begin{tabular}{|l|c|c|c|c|c|}
\hline & Kuwait & Saudi & Oman & Abu Dhabi & US Interest Rates \\
\hline Correlation Table & & & & & \\
\hline Kuwait & 1.000 & & & & \\
\hline Saudi & 1.000 & 1.000 & & & \\
\hline Oman & 0.731 & 0.731 & 1.000 & & \\
\hline Abu Dhabi & 0.582 & 0.582 & 0.757 & 1.000 & \\
\hline US Interest Rates & 0.990 & 0.990 & 0.700 & 0.569 & 1.000 \\
\hline
\end{tabular}

The third interesting conclusion to highlight is that in case of a potential decrease in interest rates (which is not realistic at the time being) might not imply opposite results. This conclusion requires further advanced independency tests because the inverse causality is not yet verified.

\section{Stock Prices Vs. Oil and Gold Prices}

As illustrated in Table 3, 79\% of the increase in interest rates is justified by the increase in oil prices. Gold prices are consequently positively affected by the same percentage. These appealing results clearly explain the reaction of the Kuwaiti, Saudi, and Omani stock markets to changes in oil prices during the same period of observation unlike Abu Dhabi market despite the existence of positive correlations. Gold prices results are only relevant for the Kuwaiti and Saudi markets. Significant correlations are marked in bold in the below table.

Table 2: Correlations Between Stock Prices and Oil, and Gold Prices

\begin{tabular}{|l|c|c|c|c|c|c|}
\hline & Kuwait & Saudi & Oman & Abu Dhabi & Oil prices & Gold Prices \\
\hline Kuwait & 1.000 & & & & & \\
\hline Saudi & 1.000 & 1.000 & & & & \\
\hline Oman & 0.731 & 0.731 & 1.000 & & & \\
\hline Abu Dhabi & 0.582 & 0.582 & 0.757 & 1.000 & & \\
\hline Oil prices & $\mathbf{0 . 7 8 9}$ & $\mathbf{0 . 7 8 9}$ & $\mathbf{0 . 7 0 0}$ & 0.474 & 1.000 & \\
\hline Gold prices & $\mathbf{0 . 7 9 8}$ & $\mathbf{0 . 7 9 8}$ & 0.248 & 0.265 & 0.503 & 1.000 \\
\hline
\end{tabular}


Table 3: Correlations Matrix Among Interest Rates, Oil, and Gold Prices

\begin{tabular}{|l|c|c|c|}
\hline & US interest rates & Oil Prices & Gold Prices \\
\hline US interest rates & 1.000 & & \\
\hline Oil Prices & $\mathbf{0 . 7 8 7}$ & 1.000 & 1.000 \\
\hline Gold Prices & $\mathbf{0 . 7 9 3}$ & 0.503 & \\
\hline
\end{tabular}

Further analysis is required to measure the significance of each factor on determining the performance of the four studied GCC stock markets.

\section{MEASURING AND TESTING THE IMPACT OF EACH FACTOR ON THE PERFORMANCE OF THE FOUR GCC SELECTED COUNTRIES}

Sometimes the existence of significant correlation cannot accurately confirm the impact on the other studied variables. In this section, we will build four regressions together with their hypothesis testing in order to determine the precise impact of the factors analyzed above on the performance of these markets.

Table 4 summarizes the output of the four regressions where the endogenous variables are price indexes and the exogenous ones are interest rates, oil, and gold prices.

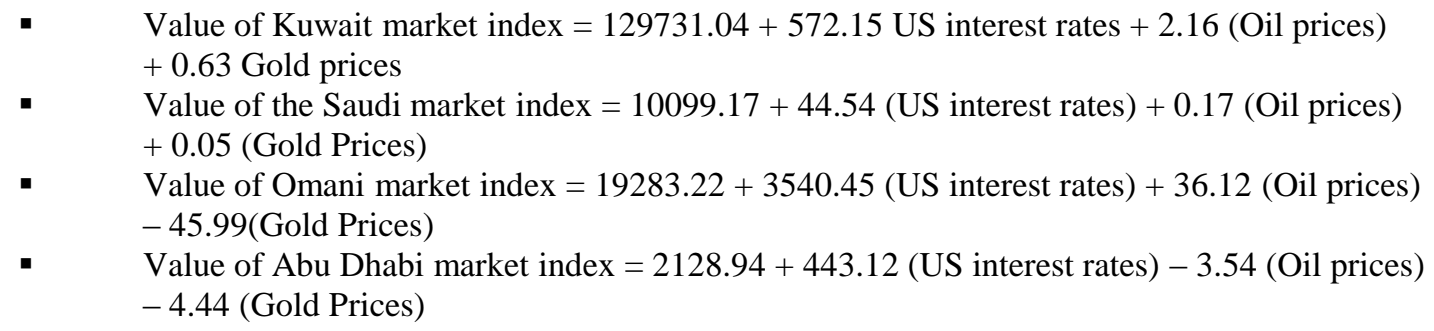

The correlation coefficients as analyzed above did not coincide with regressions results as for explaining the performance of all our studied markets. The multiple Rs corresponding to the Kuwaiti, Saudi, and the Omani markets show that actual and estimated values are very close, where $\mathrm{R}$ square for each of these countries indicate that the change in prices is due to the change in the three independent variables that we have introduced up to $98 \%$ in Kuwait and Saudi and 75\% in Oman. Abu Dhabi results are not convincing when explaining the changes in stock prices.

On the other hand, the standard error of estimate when compared to the standard deviation of stock prices is lower except for Abu Dhabi market ${ }^{11}$, which means that our model for analyzing the variability of this market is not enough and that this market is different than the three other ones. Based on the results that the four GCC markets follow a relatively normal distribution, testing the beta coefficients becomes possible ${ }^{12}$.

\section{Curious Results}

1. The common factor positively affecting stock prices in the four places is interest rates. This is confirmed through the $\mathrm{p}$-Value that is less than $1 \%$ in the four cases.

2. Oil prices variable is not as important as interest rates on shaping the tendency of the four markets despite the significant correlation results obtained in section 2.

3. It seems that Oman and Abu Dhabi stock markets are sensitive to the gold prices' variation. Both markets are negatively and significantly affected by changes due to this factor ${ }^{13}$ unlike the Saudi and Kuwaiti market.

\footnotetext{
${ }^{11}$ Refer to the bold number of 224.91

${ }^{12} \mathrm{H} 0$ : Beta $=0$, and Ha: Beta $\neq 0$

${ }^{13} \mathrm{P}$-Value is less than $1 \%$ with a confidence level of $99 \%$.
} 
Table 4: Output Summary of the Four Regressions

\begin{tabular}{|c|c|c|c|c|c|c|}
\hline & $\begin{array}{c}\text { Multiple } \\
\mathbf{R} \\
\end{array}$ & R-Square & $\begin{array}{l}\text { Adjusted } \\
\text { R-Square }\end{array}$ & $\begin{array}{l}\text { StErr of } \\
\text { Estimate }\end{array}$ & $\sigma$ & \\
\hline Kuwait & 0.990 & 0.981 & 0.980 & 47.147 & 339.72 & \\
\hline Saudi & 0.990 & 0.981 & 0.980 & 3.670 & 26.45 & \\
\hline Oman & 0.866 & 0.751 & 0.745 & 809.606 & 1603.56 & \\
\hline Abu Dhabi & 0.649 & 0.421 & 0.407 & 173.1492 & 224.91 & \\
\hline ANOVA Table & $\begin{array}{c}\text { Degrees of } \\
\text { Freedom } \\
\end{array}$ & $\begin{array}{c}\text { Sum of } \\
\text { Squares }\end{array}$ & $\begin{array}{l}\text { Mean of } \\
\text { Squares }\end{array}$ & F-Ratio & p-Value & \\
\hline \multicolumn{7}{|l|}{ Kuwait } \\
\hline Explained & 3 & 14155061.69 & 4718353.895 & 2122.665 & $<0.0001$ & \\
\hline Unexplained & 122 & 271186.918 & 2222.843 & & & \\
\hline \multicolumn{7}{|l|}{ Saudi } \\
\hline Constant & 3 & 85781.690 & 28593.896 & 2122.6667 & $<0.0001$ & \\
\hline $\begin{array}{l}\text { US interest } \\
\text { rates }\end{array}$ & 122 & 1643.430 & 13.470 & & & \\
\hline \multicolumn{7}{|l|}{ Oman } \\
\hline Explained & 3 & 241458794.1 & 80486264.7 & 122.793 & $<0.0001$ & \\
\hline Unexplained & 122 & 79966350.98 & 655461.893 & & & \\
\hline \multicolumn{7}{|l|}{ Abu Dhabi } \\
\hline Explained & 3 & 2665523.894 & 888507.964 & 29.636 & $<0.0001$ & \\
\hline Unexplained & 122 & 3657642.455 & 29980.6758 & & & \\
\hline $\begin{array}{c}\text { Regression } \\
\text { Table }\end{array}$ & Coefficient & $\begin{array}{c}\text { Standard } \\
\text { Error }\end{array}$ & t-Value & p-Value & Lower Limit & Upper Limit \\
\hline \multicolumn{7}{|l|}{ Kuwait } \\
\hline Constant & 129731.040 & 101.944 & 1272.561 & $<0.0001$ & 129529.230 & 129932.850 \\
\hline $\begin{array}{l}\text { US interest } \\
\text { rates }\end{array}$ & 572.150 & 18.760 & 30.497 & $<0.0001$ & 535.012 & 609.289 \\
\hline Oil Prices & 2.1662 & 1.116 & 1.940 & 0.0546 & -0.043 & 4.376 \\
\hline Gold Prices & 0.632 & 0.268 & 2.350 & 0.0203 & 0.099 & 1.164 \\
\hline \multicolumn{7}{|l|}{ Saudi } \\
\hline Constant & 10099.161 & 7.936 & 1272.562 & $<0.0001$ & 10083.451 & 10114.872 \\
\hline $\begin{array}{l}\text { US interest } \\
\text { rates }\end{array}$ & 44.540 & 1.460 & 30.498 & $<0.0001$ & 41.649 & 47.431 \\
\hline Oil Prices & 0.169 & 0.087 & 1.940 & 0.055 & -0.003 & 0.341 \\
\hline Gold Prices & 0.049 & 0.021 & 2.351 & 0.020 & 0.008 & 0.091 \\
\hline \multicolumn{7}{|l|}{ Oman } \\
\hline Constant & 19283.214 & 1750.589 & 11.015 & $<0.0001$ & 15817.747 & 22748.680 \\
\hline $\begin{array}{l}\text { US interest } \\
\text { rates }\end{array}$ & 3540.452 & 322.154 & 10.990 & $<0.0001$ & 2902.716 & 4178.188 \\
\hline Oil Prices & 36.122 & 19.171 & 1.884 & 0.062 & -1.829 & 74.073 \\
\hline Gold Prices & -45.988 & 4.618 & -9.959 & $<0.0001$ & -55.129 & -36.847 \\
\hline \multicolumn{7}{|l|}{ Abu Dhabi } \\
\hline Constant & 2128.938 & 374.396 & 5.686 & $<0.0001$ & 1387.784 & 2870.093 \\
\hline $\begin{array}{l}\text { US interest } \\
\text { rates }\end{array}$ & 443.123 & 68.899 & 6.432 & $<0.0001$ & 306.732 & 579.515 \\
\hline Oil Prices & -3.536 & 4.100 & -0.862 & 0.390 & -11.653 & 4.580 \\
\hline Gold Prices & -4.433 & 0.988 & -4.489 & $<0.0001$ & -6.388 & -2.478 \\
\hline
\end{tabular}




\section{Limitations}

It would have been very useful to consider more factors in our regression analysis. However, due to the lack of secondary data and to the effort we made to collect and cleansing the data piece by piece, we were not able to expand our model at this stage ${ }^{14}$.

\section{CONCLUSION}

We were able in our study to come out with new interesting findings for local and international investors and to show how some of the GCC stock markets are obviously breaking few financial principles. A perfect positive correlation between the Saudi and Kuwaiti stock market is an imposing result. Investors must be aware of such restrictive hypothesis for diversification purpose. However, this piece of information might constitute an efficient instrument for speculation. Additional interesting results are illustrated in the positive relationship between interest rates and stock prices in the four places. Oil and gold factors effect on the performance of these markets is still uncertain and not final. Lastly, Abu Dhabi seems different from the other studied markets. It has completely different behavior; it has its own system. Some other factors, not tackled in our research, must be considered to better explain the performance of this market.

\section{BIBLIOGRAPHY}

1. Barro, R. (1991), Economic Growth in a Cross-section of Countries, Quarterly Journal of Economics, 106, 407-44.

2. Dickey, D. A. and Fuller, W. A. (1979), Distributions of the Estimators for Autoregressive Time Series With a Unit Root, Journal of the American Statistical Association, 74, 427-31.

3. Johansen, S. (1988), Statistical Analysis of Cointegrating Vectors, Journal of Economic Dynamics and Control, 12, 231-54.

4. Johansen, S. (1991), Estimation and Hypothesis Testing of Cointegration in Gaussian Vector Autoregressive Models, Econometrica, 59, 1551-80.

5. Levine, R. and Renelt, D. (1992), A sensitivity Analysis of Cross-country Growth Regressions, American Economic Review, 82, 942-64.

6. Naïmy V. (2003), Marchés émergents, financement des PME et croissance économique : étude du cas libanais, NDU Press.

7. Naimy V. (2005), Measuring the Effect of Financial Liberalization On The Supply Of Credit To The Private Sector: The Case Of Lebanon. The International Business And Economics Research Journal, ISSN 15350754, Volume 4, Number 5, May 2005, p. 17-30.

8. Naimy V. (2006), The Black-Scholes Model Guideline for Options Course as Taught at Notre Dame University- Lebanon, The Journal of Business \& Economics Research, Volume 4, Number 1, January 2006, p. 59-64.

9. Naimy V. (2006), Measuring, Adjusting, and Forecasting Beta: The Case of All the Lebanese Listed Firms, The Journal of Business \& Economics Research, Volume 4, Number 4, April 2006 p. 53-63.

10. Sala-i-Martin, X. (1997), I just run two million regressions, AEA Papers and Proceedings, 87, 178-83.

11. http://portal.adsm.ae

12. http://www.kuwaitse.com/Market/MarketHistory.aspx

13. http://www.tadawul.com.sa/

14. http://www.msm.gov.om/

15. http://tonto.eia.doe.gov/dnav/pet/hist/rwtcd.htm

16. http://www.usagold.com/reference/prices/2005.html

17. http://www.federalreserve.gov/releases/

18. www.finance.gov.lb

19. $\quad$ www.Mideastweb.com

14 Wider analysis will be conducted in collaboration with the corresponding financial entities in the coming year. 
20. www.state.gov

21. WwW.worldbank.com

\section{NOTES}

